\title{
SELECTION OF ACCOMMODATION BY POLISH TOURISTS IN CROATIA
}

\author{
KAROLINA MACHCZYŃSKA, ${ }^{1}$ CZESŁAW ADAMIAK, ${ }^{2}$ VUK TVRTKO OPAČIĆ ${ }^{3}$
}

\author{
1 Nicolaus Copernicus University in Toruń \\ Faculty of Earth Sciences \\ e-mail: machczynskakarolina@gmail.com \\ 2 Nicolaus Copernicus University in Toruń \\ Faculty of Earth Sciences \\ e-mail: czeslaw.adamiak@umk.pl \\ 3 University of Zagreb \\ Department of Geography \\ e-mail: vtopacic@geog.pmf.hr
}

\begin{abstract}
\begin{tabular}{l|l} 
JEL CODES & L83, Z30
\end{tabular}
KEYWORDS tourism accommodation, Croatia, self-catering accommodation, Internet

ABSTRACT The aim of the paper is to describe the process of accommodation choice by Polish tourists visiting Croatia. It uses online survey data gathered among the users of thematic Facebook pages and internet forums. The results show a dominance of apartments and other forms of self-catering accommodation among the accommodation services used by Polish tourists. They point at the importance of Internet information sources in accessing the information and purchasing accommodation services. Location by the sea, price, and cleanness proved to be important motives for accommodation selection. Besides the dominant group of online-booking self-catering accommodation users, there were less numeric groups of more traditional hotel users using traditional travel agencies, and camping users looking for accommodation on site.
\end{abstract}

\section{Introduction}

The accommodation sector is one of the most significant components of the tourism industry. Tourism accommodation services vary in terms of their technical and organisational form and the array of services provided. Besides commercial accommodation services, there are also non-commercial forms of accommodation for tourists: staying with relatives and friends, or in private second homes (Garrod, 2012). There are two trends in the recent development of the accommodation 
market that require further attention: the first is the increasing use of the Internet media in marketing tourism services, including accommodation (Pawlicz, 2012; Standing, Tang-Taye, Boyer, 2014). The second is the development of self-catering forms of accommodation including timeshares, rental of apartments and holiday homes (Więckowski, 2014).

Internet communication is increasingly used to sell tourism services, including airline tickets, car rentals, accommodation, cruises, and tourist packages (Buhalis, 2003). It has affected the purchase behaviour of tourists in two ways, leading to the processes of disintermediation and reintermediation. The first term refers to the increasingly popular direct purchases of tourist services from their suppliers (airlines, hotels) through their webpages rather than using the travel agencies as intermediaries (Law et al., 2015). Re-intermediation, in turn, is the development of new intermediaries (Palmer, McCole, 1999): online travel agents (e.g. Booking.com, Expedia), metasearch engines (e.g. Kayak, Trivago), online review aggregators (TripAdvisor), and sharing economy platforms (e.g. Airbnb, HomeAway). They fulfil the role of traditional agents: aggregate information on available products, ease the purchase process, and increase the sense of security (Kowalska, 2018). Moreover, such new intermediaries provide tourists with the access to reviews and ratings posted by other customers, which are influential in the choice of accommodation (Gretzel, Yoo, 2008).

The other trend in tourism accommodation that has to be taken into account is the growing number and role of the forms of self-catering accommodation, which differ from hotels and similar establishments by not providing services such as meals, reception and daily cleaning. Such places, in their technical form and location, are often closer to residential housing, hence such a model of tourism development is also called residential tourism (Perles-Ribes, Ramón-Rodríguez, Such-Devesa, 2018). Self-catering accommodation services include rental apartments, holiday homes, timeshares, and are often related to second home tourism (Hall, Müller, 2018). Their growing popularity is related to the development of Internet mediators: holiday apartments and homes are marketed through online travel agents, and the development of peer-to-peer accommodation has made it possible to provide accommodation services in private flats creating a whole new stock of tourism accommodation particularly in large cities (Dolnicar, 2018).

For marketing and management of destinations it is important to understand how the tourists take their decisions on choosing accommodation: both type and particular provider. In this paper we try to contribute to this understanding by focusing on the market of Croatia, an important summer holiday destination in Europe. We use survey data on Polish tourists who have visited Croatia to answer the following exploratory research questions. First, what types of accommodation are used by Polish tourists visiting Croatia? Second, how do they access information on accommodation and book the accommodation? Third, what factors affect their selection of accommodation? And fourth, what specific groups of tourists with similar characteristics of accommodation purchase behaviour can we distinguish and how do they differ from each other? 


\section{Tourism in Croatia}

Tourism in Croatia is mostly developed along the Adriatic coast, in the regions of Dalmatia, Kvarner and Istria. These regions are characterised by the Mediterranean and sub-Mediterranean climate with hot and sunny summers, and rugged coastline, full of peninsulas and islands. There are also historic attractions, in the cities of Dubrovnik, Trogir, and Split, to name a few. Tourism in Croatian interior is less developed, and its major tourism centres are the capital city of Zagreb and Plitvice Lakes National Park. With population of only 4.1 million inhabitants (Eurostat, 2018a) the country creates relatively little domestic demand for tourism, so its tourism potential is used principally by international tourists. In 2017, Croatia was visited by 15.6 million foreign tourists $(71.1 \%$ more than in 2010) making it the 14th largest international tourism destination in Europe, according to the UNWTO statistics (UNWTO, 2017). Croatia is the second country in the EU (after Malta) in terms of tourism intensity measured by guest nights spent in accommodation establishments per inhabitant (Eurostat, 2018b). Croatian economy is highly reliant on tourism: in 2017, tourism generated $19.6 \%$ of the country's GDP (Ministry of Tourism..., 2018a), compared to 3.9\% direct contribution of tourism to the total GDP of the EU (WTTC, 2018).

Croatia is a popular vacation destination for Polish tourists. Besides suitable conditions described above, relatively close distance and well developed road linkage between the countries enable easy access by private car. According to the Croatian Ministry of Tourism, in 2017, 934 thousand Polish tourists visited the country spending 6.1 million nights there. It puts Poland on the fifth place among countries in terms of number of visits (after Germany, Austria, Slovenia and Italy), and the fourth place in terms of overnights (ahead of Italy, Ministry of Tourism..., 2018b). According to the Polish statistical office, there were 683.8 thousand tourist trips of Polish residents to Croatia in 2017 (only people at least 15 years old are included in this number, hence the difference between Polish and Croatian data), which put the country on the fifth place of Polish tourists' destinations, after Germany, Italy, the UK and the Czech Republic. Yet, if only leisure travels are taken into account (excluding e.g. VFR and business trips), Croatia reaches the second place, only after Italy (GUS, 2018). Trips to Croatia are only 1.5\% of all summer trips organised by Polish tour operators (Polish Chamber of Tourism, 2018), which means that the vast majority of trips from Poland to Croatia are individually planned.

\section{Data}

The study reports the results of an Internet survey, gathered in March 2018. We published an invitation to respond to the survey on several thematic Facebook groups and Internet forums. Facebook groups are: "Chorwacja" (Croatia), "Chorwacja - podróże" (Croatia - travels), and "Chorwacja noclegi w Chorwacji" (Croatia - accommodation in Croatia). At that time, these groups had between 13 and 30 thousand members, who used the groups to ask questions to other members about transport, accommodation and tourist attractions in Croatia, and to share own experiences from trips to this country. Internet forums where we published the survey are: cro.pl and grobtroter.pl. The former one is a Polish forum devoted specifically to present tourist information on Croatia. 
The latter forum has wider scope and covers tourist information on various countries, including Croatia.

The survey consisted of 11 questions regarding respondents' experience in travelling to Croatia, and their choice of accommodation, as well as 5 questions about the socio-demographic status of the respondents. The survey was conducted with the use of LimeSurvey online surveying system, and the results were later summarised, analysed and presented using R software.

\section{Sample description}

In total, 929 respondents answered the survey. After excluding incomplete responses, 777 surveys were used in further analysis. Out of them, 31 respondents did not answer one or more sociodemographic questions, but we still used these responses as missing data did not affect the analysis.

Most respondents are female (79.3\%), young and middle-aged $(72.6 \%$ between 26 and 45 years old, tab. 1). They usually have higher or secondary education and are working (employed or running their own businesses). The composition of the group in terms of places of residence is similar to the distribution of entire population, with slight underrepresentation of the residents of rural areas and small cities, and overrepresentation of the residents of middle-sized and large cities. The socio-demographic composition of the sample probably reflects the structure of Polish tourists visiting Croatia. It may be biased though by the method used, leading to the overrepresentation of people in young and middle age, and females.

Table 1. Socio-demographic structure of the sample

\begin{tabular}{|c|c|c|c|}
\hline Variable & Value & Frequency & Percentage \\
\hline \multirow{3}{*}{ Sex } & female & 616 & 79.3 \\
\hline & male & 153 & 19.7 \\
\hline & no answer & 8 & 1.0 \\
\hline \multirow{8}{*}{ Age } & less than 19 years & 5 & 0.6 \\
\hline & $19-25$ years & 65 & 8.4 \\
\hline & $26-35$ years & 240 & 30.9 \\
\hline & $36-45$ years & 324 & 41.7 \\
\hline & $46-55$ years & 100 & 12.9 \\
\hline & $56-65$ years & 29 & 3.7 \\
\hline & over 65 years & 7 & 0.9 \\
\hline & no answer & 7 & 0.9 \\
\hline \multirow{5}{*}{ Education } & primary & 5 & 0.6 \\
\hline & vocational & 28 & 3.6 \\
\hline & secondary & 263 & 33.8 \\
\hline & higher & 474 & 61.0 \\
\hline & no answer & 7 & 0.9 \\
\hline \multirow{6}{*}{ Professional status } & working & 645 & 83.0 \\
\hline & student & 54 & 6.9 \\
\hline & unemployed & 26 & 3.3 \\
\hline & retired & 22 & 2.8 \\
\hline & other & 16 & 2.1 \\
\hline & no answer & 12 & 1.5 \\
\hline
\end{tabular}




\begin{tabular}{|c|c|c|c|}
\hline Variable & Value & Frequency & Percentage \\
\hline \multirow{4}{*}{ Place of residence } & rural area & 152 & 19.6 \\
\cline { 2 - 4 } & city $<20$ thousand inhabitants & 84 & 10.8 \\
\cline { 2 - 4 } & city 20-100 thousand inhabitants & 189 & 24.3 \\
\cline { 2 - 4 } & city 100-500 thousand inhabitants & 200 & 25.7 \\
\cline { 2 - 4 } & city over 500 thousand inhabitants & 145 & 18.7 \\
\cline { 2 - 4 } & no answer & 7 & 0.9 \\
\hline
\end{tabular}

Source: own study.

Most of the sample members have been to Croatia more than once (tab. 2). During their last trips, most of respondents spent between one and two weeks (84.5\%) in Croatia, and travelled with their families or partners $(88.4 \%)$.

Table 2. Trips to Croatia of the sample members

\begin{tabular}{|c|c|c|c|}
\hline Variable & Value & Frequency & Percentage \\
\hline \multirow{4}{*}{ Number of trips to Croatia so far } & 1 & 164 & 21.1 \\
\cline { 2 - 4 } & $2-3$ & 242 & 31.1 \\
\cline { 2 - 4 } & $4-5$ & 143 & 18.4 \\
\cline { 2 - 4 } & more than 5 & 228 & 29.3 \\
\hline \multirow{4}{*}{ Length of last stay in Croatia } & $1-3$ days & 5 & 0.6 \\
\cline { 2 - 4 } & $4-6$ days & 38 & 4.9 \\
\cline { 2 - 4 } & $7-10$ days & 309 & 39.8 \\
\cline { 2 - 4 } & $11-14$ days & 78 & 10.7 \\
\hline \multirow{3}{*}{$\begin{array}{l}\text { Company during last trip to } \\
\text { Croatia }\end{array}$} & 15 days and more & 540 & 69.5 \\
\cline { 2 - 4 } & with family & 147 & 18.9 \\
\cline { 2 - 4 } & with partner & 55 & 10.9 \\
\hline
\end{tabular}

Source: own study.

We asked the respondents to write the name of the exact place where they were during their last visit to Croatia. Some respondents wrote a list of places that they visited, in these cases we took into account only the first place mentioned. Then, we assigned the localities to administrative units (županijas - NUTS 3 units). Great majority (99.4\%) of respondents spent their time in one of the coastal regions, the remaining $0.6 \%$ visited the capital region - City of Zagreb. Among coastal regions, Central Dalmatia was the most popular (fig. 1). 


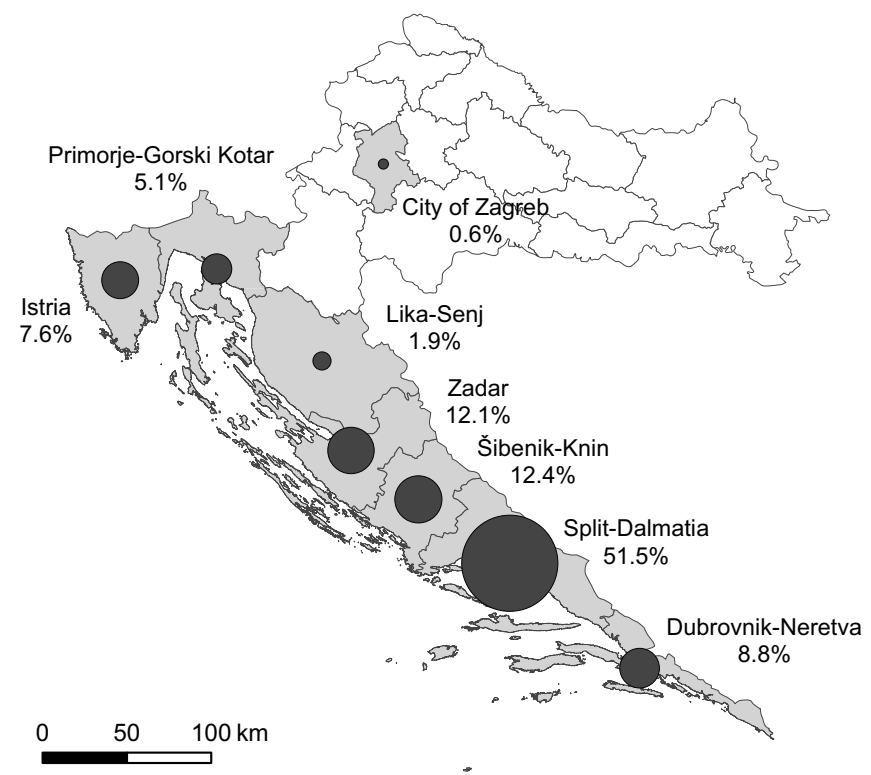

Figure 1. Regions (županijas) visited by respondents

Source: own study.

\section{Choice of accommodation in Croatia}

The classification and categorisation of tourism accommodation services in Croatia is regulated by the Ministry of Tourism. All tourism accommodation establishments are divided into three main groups: hotel establishments, camping establishments and homestays run by individual persons. The three groups are further divided into more precise kinds of establishments. Hotel establishments are the following: historical (baština) hotels, dispersed (difuzni) hotels, hotels, aparthotels, tourist resorts (turističko naselje), tourist apartments, pensions, integrated (integralni) hotels, SPA, hotels with special standard (posebnog standarda). Camping establishments are divided into two kinds: campsites (kamp) and recreational vehicle parks (kamp odmorište). There are six types of homestays: rooms (sobe), apartments (apartman), studio apartments, holiday homes (kuća za odmor), and both types of camping, if they are operated by individuals.

In the survey, we did not expect Polish tourists to know exact formal classification of the accommodation service that they used. We created a simpler typology of eight types of accommodation services. For clarity, we wrote a short description of each of them in the survey. The types included: tourist resort, hotel, SPA, apartment, private room, holiday home, hostel, camping. We asked respondents about the kinds of accommodation they used during all their trips to Croatia (multiple answers were allowed), and the accommodation they used during their last trip (single 
answer). A few respondents could not find suitable answer among the eight suggestions, and provided other answers. These included: yacht, friends or relatives' house, and wild camping, among others.

Tourist apartments turned out to be by far the most commonly used kind of accommodation by Polish tourists in Croatia (fig. 2). $76.7 \%$ of the respondents used it during any of their visits, and $71.6 \%$ did it during their last visit. Other forms of self-catering accommodation: private rooms and campsites held the second and third place, and holiday homes were on the fifth place. Hotels were only on the 4 th place with $9.3 \%$ of total users and $5.4 \%$ of last-visit users. Tourist resorts were even less popular, hostels and SPAs were selected only by individual cases.

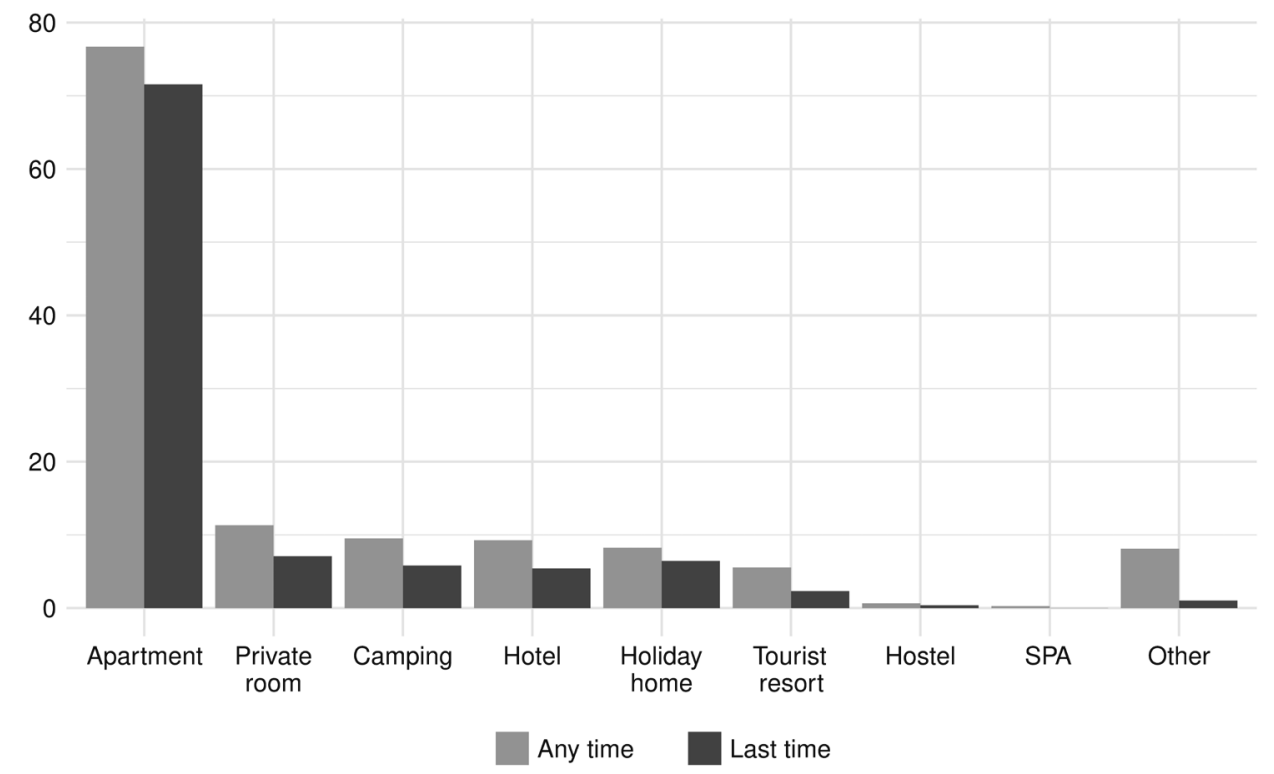

Figure 2. Share (\%) of respondents using various types of accommodation during any of their visits, and during their last visit to Croatia

Source: own study.

Most of surveyed tourists booked their accommodation well in advance of their trip, yet $16.2 \%$ did it only after arriving to the country (tab. 3). The respondents extensively used Internet channels when booking their accommodation: more than one third did it through an online travel agency, such as Booking.com, and almost every fourth respondent - directly through the webpage of the accommodation provider. Most of $8.1 \%$ respondents who choose "other" answer did the reservation through Internet as well, providing answers such as: through email, Facebook, Messenger, or stating specific OTA or accommodation webpage, such as Airbnb. It was much less common to use traditional travel agency or book via telephone, or to purchase accommodation on site, without prior booking. Internet sources were equally important before booking, during the search for possible accommodation: OTAs, Internet forums and social media were more commonly used than 
advices of relatives and friends, local residents, and traditional travel agencies. Again, other respondents' answers pointed at more types of Internet sources (Google, Google Maps, and Croatian accommodation search engines).

Table 3. Trips to Croatia of the sample members

\begin{tabular}{|c|c|c|c|}
\hline Variable & Value & Frequency & Percentage \\
\hline \multirow{5}{*}{$\begin{array}{l}\text { Time of booking } \\
\text { accommodation }\end{array}$} & more than 6 months before trip & 236 & 30.4 \\
\hline & $6-4$ months before trip & 226 & 29.1 \\
\hline & $3-1$ months before trip & 125 & 16.1 \\
\hline & within 1 month before trip & 64 & 8.2 \\
\hline & on site, after arriving to Croatia & 126 & 16.2 \\
\hline \multirow{6}{*}{$\begin{array}{l}\text { Method of booking } \\
\text { accommodation }\end{array}$} & with online travel agency (e.g. Booking.com) & 269 & 34.6 \\
\hline & on the webpage of the object & 183 & 23.6 \\
\hline & on site & 131 & 16.3 \\
\hline & with travel agency & 76 & 9.8 \\
\hline & by telephone & 55 & 7.1 \\
\hline & other & 63 & 8.1 \\
\hline \multirow{7}{*}{$\begin{array}{l}\text { Sources of information used } \\
\text { when selecting accommodation } \\
\text { (multiple answers possible) }\end{array}$} & online travel agency(e.g. Booking.com) & 391 & 50.3 \\
\hline & internet forums & 279 & 35.9 \\
\hline & $\begin{array}{l}\text { thematic groups in social media } \\
\text { (e.g. Facebook) }\end{array}$ & 221 & 28.4 \\
\hline & relatives and friends & 216 & 27.8 \\
\hline & local residents & 127 & 16.3 \\
\hline & travel agency & 71 & 9.1 \\
\hline & other & 32 & 4.1 \\
\hline
\end{tabular}

Source: own study.

In the last part of the survey, we asked the respondents about the importance of various motives for their decisions on the choice of accommodation. 14 motives were evaluated on 1 (not important at all) to 5 (very important) scale. Cleanness, distance to the sea and price turned out to be the most important of all motives (average response over 4, fig. 3). Among the features of the accommodation establishment, the respondents highly valued its amenities and size of room/flat, while the presence of additional services and catering in the place were the least important features. It could be expected taking into account that the majority of respondents use self-catering accommodation services. Location characteristics, besides very important proximity to the sea, were in the middle of the list. Opinions were important as well, but electronic word-of-mouth was higher valued than direct one: opinion of family and friends. 


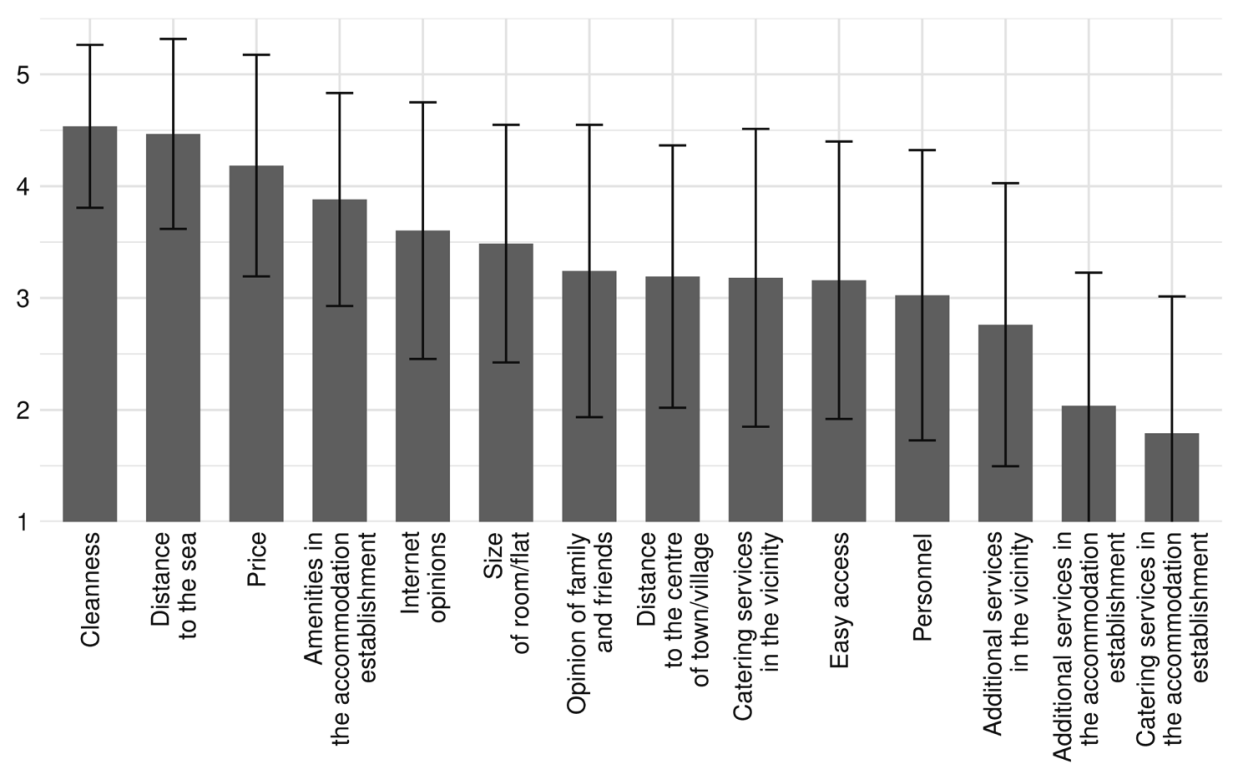

Figure 3. Average importance of motives for decisions of respondents on the selection of accommodation. Whiskers indicate standard deviation of responses

Source: own study.

\section{Typology of tourists according to the choice of accommodation}

Based on the answers to the question about the type of accommodation used during their last visit to Croatia, and about the method of booking accommodation, we created a typology of respondents with similar accommodation selection behaviour. To find the groups we used k-modes method, which is an extension of the k-means clustering method to be used with categorical data (Huang, 1998). We selected the 4-cluster solution based on the application of the elbow method (Kodinariya, Makwana, 2013). Then, we took into account only the typical cases, so those where answers to both questions were equal to the modes in given cluster. 55.6\% respondents fell into one of four typical categories. Their characteristics are summarized in table 4.

We distinguished two large and two smaller groups of respondents. The first two groups are apartment users. The first group booked them through the own webpages of the accommodation providers, while the second group used online travel agents. It can be assumed from the results that people switch from OTAs to specific webpages when they gain more experience and do not have to rely on online opinions anymore. Members of cluster 3 stayed in campsites and booked accommodation after arriving to Croatia. They are typically in older age, have large experience in travels to Croatia, stay there for long and have low expectations towards the amenities in the accommodation site. The members of cluster 4 stay in hotels that were booked through traditional travel agencies. This group includes tourists who take part in organized trips. They are usually older than average, 
they go to Croatia for the first time and for a short stay. The motives they take into account when choosing accommodation are also different from those of the rest of the sample.

Table 4. Characteristics of four types of Polish tourists visiting Croatia

\begin{tabular}{|l|c|l|l|l|l|l|}
\hline $\begin{array}{c}\text { Cluster } \\
\text { number }\end{array}$ & $\begin{array}{c}\text { Size } \\
\text { of cluster }\end{array}$ & $\begin{array}{c}\text { Mode: } \\
\text { type of } \\
\text { accommodation }\end{array}$ & $\begin{array}{c}\text { Mode: method } \\
\text { of booking }\end{array}$ & $\begin{array}{c}\text { Distinctive } \\
\text { socio-demographic } \\
\text { characteristics }\end{array}$ & $\begin{array}{c}\text { Distinctive } \\
\text { characteristics of trips }\end{array}$ & Distinctive motives \\
\hline $\begin{array}{c}148 \\
(19.0 \%)\end{array}$ & apartment & $\begin{array}{l}\text { on the webpage } \\
\text { of the object }\end{array}$ & $36-55$ years old & $\begin{array}{l}\text { Experienced in trips to } \\
\text { Croatia. } \\
\text { Stay more than } 10 \text { days. } \\
\text { With family }\end{array}$ & $\begin{array}{l}\text { Inexperienced in trips to } \\
\text { Croatia. } \\
\text { Stay about 1 week. } \\
\text { With partner or family }\end{array}$ & important: internet opinions \\
\hline 3 & $\begin{array}{c}219 \\
(28.2 \%)\end{array}$ & apartment & $\begin{array}{l}\text { with online } \\
\text { travel agency } \\
\text { (e.g. Booking. } \\
\text { com })\end{array}$ & $19-45$ years old \\
$(4.0 \%)$ & camping & on site & $>55$ years old & $\begin{array}{l}\text { Experienced in trips to } \\
\text { Croatia. } \\
\text { Stay more than 2 weeks. } \\
\text { With partner }\end{array}$ & $\begin{array}{l}\text { unimportant: size of room, } \\
\text { amenities, distance to the } \\
\text { centre, opinions of family } \\
\text { and friends }\end{array}$ \\
\hline 4 & $\begin{array}{c}34 \\
(4.4 \%)\end{array}$ & hotel & $\begin{array}{l}\text { with travel } \\
\text { agency }\end{array}$ & $>55$ years old & $\begin{array}{l}\text { First trip to Croatia. } \\
\text { Stay about 1 week. } \\
\text { Alone or with partner }\end{array}$ & $\begin{array}{l}\text { important: catering and } \\
\text { additional services in the } \\
\text { accommodation, easy access }\end{array}$ \\
\hline Others & $\begin{array}{c}345 \\
(44 \%)\end{array}$ & & & & \\
\hline
\end{tabular}

Source: own study.

\section{Conclusions}

According to the results of the survey, apartments and other forms of self-catering accommodation are the most popular types of tourist accommodation used by Polish tourists in Croatia. It is only a minority who use hotels, tourist resorts or even camping places. Moreover, the more experienced a tourist is, the more probable $\mathrm{s} /$ he is to choose this kind of self-catering accommodation. There are quite specific groups of mainly older tourists, who use hotels and campsites. Apartments were particularly popular among travellers with families (75.7\% of them chose apartments). The second important conclusion is about the dominant role that Internet media play in both accessing information about accommodation opportunities, and purchasing accommodation services. Two thirds of the respondents used webpages, OTAs, e-mails or other Internet media to book their stay. Half of the remaining "traditional" accommodation users are last-time bookers who went to Croatia without prior reservation of accommodation. The rest are those who use traditional travel agencies or telephone. Online booking was correlated with the inclination towards self-catering forms of accommodation. Hotels, hostels and tourist resorts were mainly booked through traditional agencies, campsites - on site, but three quarters of apartments and holiday homes were booked via Internet.

The limitations of the study mainly derive from the method of accessing respondents for the online survey: they were recruited through the Internet forums and thematic Facebook pages, which might cause multiple bias in the sample selection. Out of the total population of Polish tourists who have visited Croatia, the users of such webpages are likely to be people who intend to 
go to Croatia again, independent tourists rather than participants of organised trips, and people used to Internet communication, usually young and middle-aged ones. There are also specific features of Polish tourists which distinguish them from other nationalities. In fact, tourists from most of other countries are more probable to use hotel or camping accommodation when visiting Croatia (Ministry of Tourism, 2018b). Further studies on international samples could shed more light on the general accommodation choice patterns.

\section{References}

Buhalis, D. (2003). eTourism: Information Technology for Strategic Tourism Management. London: Pearson.

Dolnicar, S. (ed.) (2018). Peer-to-peer Accommodation Networks: Pushing the Boundaries. Oxford: Goodfellow Publishers.

Eurostat (2018a). Population: main tables. Retrieved from: https://ec.europa.eu/eurostat/web/population-demographymigration-projections/population-data/main-tables (31.10.2018).

Eurostat (2018b). Tourism Statistics - Annual Results for the Accommodation Sector. Retrieved from: https://ec.europa. eu/eurostat/statistics-explained/index.php/Tourism_statistics_-_annual_results_for_the_accommodation_sector (31.10.2018).

Garrod, B. (2012). Accommodation Providers. In: P. Robinson (ed.), Tourism: The Key Concepts (pp. 3-7). London: Routledge.

Gretzel, U., Yoo, K.H. (2008). Use and Impact of Online Travel Reviews. In: P. O’Connor, W. Höpken, U. Gretzel (eds.), Information and Communication Technologies in Tourism (pp. 35-46). Vienna: Springer.

GUS (2018). Turystyka w 2017 r. Retrieved from: https://stat.gov.pl/obszary-tematyczne/kultura-turystyka-sport/turystyka/turystyka-w-2017-roku,1,15.html (31.10.2018).

Hall, C.M., Müller, D. (2018). Second Home Tourism: An Introduction. In: C.M. Hall, D. Müller (eds.), The Routledge Handbook of Second Home Tourism and Mobilities (pp. 3-14). Abingdon: Routledge.

Huang, Z. (1998). Extensions to the k-Means Algorithm for Clustering Large Data Sets with Categorical Values. Data Mining and Knowledge Discovery, 2, 283-304.

Kodinariya, T.M., Makwana, P.R. (2013). Review on determining number of Cluster in K-Means Clustering. International Journal of Advance Research in Computer Science and Management Studies, 1 (6), 90-95.

Kowalska, K. (2018). Konkurencyjność podmiotów sharing economy w turystyce. Ekonomiczne Problemy Turystyki, 2 (42), 19-27.

Law, R., Leung, R., Lo, A., Leung, D., Nang Fong, L.H. (2015). Distribution channel in hospitality and tourism. International Journal of Contemporary Hospitality Management, 3 (27), 431-452.

Ministry of Tourism Republic of Croatia (2018a). Ostvareni prihodi u 2017. godini potvrda su velikog napretka hrvatskog turizma. Retrieved from: https://mint.gov.hr/vijesti/ostvareni-prihodi-u-2017-godini-potvrda-su-velikog-napretka-hrvatskog-turizma/12079 (7.11.2018).

Ministry of Tourism Republic of Croatia (2018b). Tourism in Figures 2017. Retrieved from: https://mint.gov.hr/ UserDocsImages//AA_2018_c-dokumenti//180608_HTZTUBENG_2017.PDF (31.10.2018).

Palmer, A., McCole, P. (1999). The virtual re-intermediation of travel services: A conceptual framework and empirical investigation. Journal of Vacation Marketing, 1 (6), 33-47.

Pawlicz, A. (2012). E-turystyka. Warsaw: Wydawnictwo Naukowe PWN.

Perles-Ribes, J.F., Ramón-Rodríguez, A.B., Such-Devesa, M.J. (2018). Second homes vs. residential tourism: A research gap. Tourism, 1 (66), 104-107.

Polish Chamber of Tourism (2018). Zagraniczne wakacje Polaków 2018 - raport Polskiej Izby Turystyki. Retrieved from https://www.travelplanet.pl/blog/zagraniczne-wakacje-polakow-2018-raport-polskiej-izby-turystyki/ (31.10.2018).

Standing, C., Tang-Taye, J.P., Boyer, M. (2014). The Impact of the Internet in Travel and Tourism: A Research Review 2001-2010. Journal of Travel \& Tourism Marketing, 1 (31), 82-113.

UNWTO (2017). Tourism Highlights. Retrieved from https://www.e-unwto.org/doi/book/10.18111/9789284419876 (31.10.2018). 
Więckowski, M. (2014). Zakwaterowanie z wyżywieniem we własnym zakresie (self-catering accommodation) - zarys problemu. Zeszyty Naukowe Uniwersytetu Szczecińskiego, 807. Ekonomiczne Problemy Turystyki, 3, $243-257$.

WTTC (2018). Travel \& Tourism Economic Impact 2018: Croatia. Retrieved from https://www.wttc.org/-/media/files/ reports/economic-impact-research/countries-2018/croatia2018.pdf (31.10.2018).

\section{WYBÓR ZAKWATEROWANIA PRZEZ POLSKICH TURYSTÓW W CHORWACJI}

SŁOWA KLUCZOWE

STRESZCZENIE zakwaterowanie turystyczne, Chorwacja, zakwaterowanie z własnym wyżywieniem, Internet

Artykuł opisuje wybory zakwaterowania przez polskich turystów odwiedzających Chorwację. Badanie oparto o wyniki ankiety internetowej przeprowadzonej wśród użytkowników tematycznych stron na Facebooku i forów internetowych. Większość respondentów korzysta z apartamentów i innych form zakwaterowania z własnym wyżywieniem. W świetle wyników najistotniejszymi źródłami informacji i kanałami zakupu usług noclegowych są serwisy internetowe. Najważniejszymi motywami wyboru zakwaterowania okazały się położenie nad morzem, cena i czystość. Poza dominującą grupą osób rezerwujących zakwaterowanie z własnym wyżywieniem, wyróżniono mniej liczne grupy turystów korzystających z usług hoteli i tradycyjnych biur podróży, oraz użytkowników kempingów szukających zakwaterowania na miejscu. 